|| ISSN(online): 2589-8698 || ISSN(print): 2589-868X || International Journal of Medical and Biomedical Studies

Available Online at www.ijmbs.info

Volume 3, Issue 2; February: 2019; Page No. 202-205

PubMed (National Library of Medicine ID: 101738825)

Index Copernicus Value 2017: 40.03

\title{
DIAGNOSTIC VALUUE OF FINE NEEDLE ASPIRATION CYTOLOGY (FNAC) BIOPSY AND LYMPH NODES IN BREAST TUMOURS
}

\section{Dr. Surendra Kumar Dhruv}

Associate Professor Dept. of Pathology Govt. Medical College Badaun UP.

Article Info: Received 29 January 2019; Accepted 10 February. 2019

Cite this article as: Dhruv, S. K. (2019). DIAGNOSTIC VALUUE OF FINE NEEDLE ASPIRATION CYTOLOGY (FNAC) BIOPSY AND

LYMPH NODES IN BREAST TUMOURS. International Journal of Medical and Biomedical Studies, 3(2).

DOI: https://doi.org/10.32553/ijmbs.v3i2.824

Address for Correspondence: Dr. Surendra Kumar Dhruv, Associate Professor Dept. of Pathology Govt. Medical College Badaun. U.P.

Conflict of interest: No conflict of interest.

\section{Abstract}

Introduction: Breast cancer is the most common solid cancer in women and one of the leading causes of cancer deaths in the western countries. In India it is a leading cause for mortality and morbidity. Prognosis of invasive ductal carcinoma (IDC) of breast is determined by anatomic extent of the disease and can be assessed by tumor size, lymph node status and metastasis, also biologic markers such as histological grade, hormone receptor expression, HER2 overexpression, and/or amplification and genomic panels can be used. The presence of metastatic in axillary lymph nodes confirms the capacity of a cancer to metastasize. It represents the single most prognostically potent element of clinical stage in potentially curable cases. Axillary lymph node dissection and histological evaluation has a continuing place in the staging and management of patients with breast cancer. It has been shown that cytological grade correlates well with the axillary lymph nodal metastasis and also prognosis. Axillary lymph node evaluation in breast cancer is usually performed preoperatively by clinical examination, sonography, lymph node resection and by ultrasound-guided fine-needle aspiration cytology.

Material and Methods: Patients with detected breast mass (palpable and non-palpable) and palpable axillary lymph node who were evaluated by FNAC. After sterile draping and sufficient disinfection, a 10-ml syringe was inserted into and withdrawn from the lymph node three times under aspiration while sonographically monitored. The procedure was performed by using 21-22 Gauge needle with 2-4 aspirations and it was repeated if the sample was inadequate. Ultrasound guided FNAC was performed for impalpable, and deeply located small lumps.

Results: A total of 156 patients were underwent for FNAC of the breast lump. Histological correlation of all the patients was done. The mean age of patients who underwent FNAC was $39.6 \pm 9.42$ years and all were female patients. The cytology reports were classified as benign, atypical, suspicious, malignancy, and unsatisfactory. In $59(37.8 \%)$ cases benign lesions were observed of which the fibrocystic disease was the most common cytological diagnosis. 15 (9.6\%) were atypical, 7(4.5\%) were suspicious and in 72(46.2\%) cases malignancy was diagnosed. In 3 (1.9\%) cases sample was unsatisfactory. FNAC of the axillary lymph nodes was performed on 76 patients with palpable lymph nodes and histological correlation of axillary lymph node. In FNAC and histology correlation of axillary lymph node sensitivity was $81.94 \%$ (95\% Cl $71.11 \%$ to $90.02 \%$ ) and specificity was 100\% (95\% Cl39.76\% to $100.00 \%)$ with positive predictive value of $100 \%$.

Conclusion: FNAC is a rapid, cost effective and safe procedure for management of breast lumps.

\section{Introduction:}

Breast cancer is the most common solid cancer in women and one of the leading causes of cancer deaths in the western countries'. In India it is a leading cause for mortality and morbidity.
Prognosis of invasive ductal carcinoma (IDC) of breast is determined by anatomic extent of the disease and can be assessed by tumour size, lymph node status and metastasis, also biologic markers such as histological grade, hormone 
receptor expression, HER2 overexpression, and/or amplification and genomic panels can be used".

Breast tissue is made up of various tissue components, also there is change in composition of breast tissue with hormonal changes. So, it has varied pathology, and there are various modalities for the diagnosis. It is important for the clinician to examine properly and take proper decision during evaluation of a patient with palpable breast massiii. The TNM staging of disease continues to provide quantitative classification categories for the primary tumour $(T)$, regional lymph nodes $(N)$, and distant metastases (M), which are combined to determine overall stage groups which are associated with overall survival and disease-free survival $^{\text {iv. }}$. The presence of metastatic in axillary lymph nodes confirms the capacity of a cancer to metastasize. It represents the single most prognostically potent element of clinical stage in potentially curable cases. Axillary lymph node dissection and histological evaluation has a continuing place in the staging and management of patients with breast cancerv ${ }^{v}$.

The false negative rate has decreased to less than $1 \%$ by Triple assessment of breast mass. But FNAC can be done as an outpatient procedure and it helps in rapid diagnosis. But there are limitations of FNAC which include difficulty to differentiate ductal carcinoma in situ (DCIS), atypical ductal hyperplasia from low grade DCIS, and fibroadenoma from phyllodes tumor ${ }^{\text {vi }}$. It has been shown that cytological grade correlates well with the axillary lymph nodal metastasis and also prognosis ${ }^{\text {vii. }}$. Regional lymph node recurrence is uncommon in patients and has been reported in 1 to $3 \%$ of patients with early stage breast cancer and in 1.7 to $15.9 \%$ of patients with any stage of breast cancer viii. Loco-regional recurrence includes recurrent disease in the diseased breast and the ipsilateral lymph nodes in the axillary, the supra- and infraclavicular and the internal mammary region. Regular follow-up exams include physical examination, mammography and sonography and, in unclear breast findings and magnetic resonance tomographyix. Axillary lymph node evaluation in breast cancer is usually performed preoperatively by clinical examination, sonography, lymph node resection and by ultrasound-guided fine-needle aspiration cytology $(\text { FNAC })^{x}$. FNAC can achieve high accuracy, sensitivity and specificity

\section{Material and Methods}

Patients with detected breast mass (palpable and non-palpable) and palpable axillary lymph node who were evaluated by FNAC. Prior to ultrasound-guided FNAC, written informed consent was obtained from each patient. Histopathological correlation was done. After sterile draping and sufficient disinfection, a 10$\mathrm{ml}$ syringe was inserted into and withdrawn from the lymph node three times under aspiration while sonographically monitored. The procedure was performed by using 21-22 Gauge needle with 2-4 aspirations and it was repeated if the sample was inadequate. Ultrasound guided FNAC was performed for impalpable, and deeply located small lumps. The FNAC cytology sample was concentrated by centrifugation. The supernatant was removed, and the pellet was resuspended. The slide was stained with Papanicolaou stain, covered with a coverslip, and evaluated. Cytoblock was cut in $3 \mu \mathrm{m}$ slices and the slides were stained in Hematoxylin/Eosin

Statistical analysis was done using Statistical software SPSS 21.0 and MedCalc 9.0.1

\section{Results}

A total of 156 patients were underwent for FNAC of the brest lump. Histological correlation of all the patients was done. The mean age of patients who underwent FNAC was $39.6 \pm 9.42$ years and all were female patients. The cytology reports were classified as benign, atypical, suspicious, malignancy, and unsatisfactory. 
Table 1: Cytology of the patients who underwent FNAC

\begin{tabular}{|l|l|}
\hline Cytology & $\mathrm{N}=156$ \\
\hline Benign & $59(37.8 \%)$ \\
\hline Atypical & $15(9.6 \%)$ \\
\hline Suspicious & $7(4.5 \%)$ \\
\hline Malignancy & $72(46.2 \%)$ \\
\hline Unsatisfactory & $3(1.9 \%)$ \\
\hline
\end{tabular}

In 59 (37.8\%) cases benign lesions were observed of which the fibrocystic disease was the most common cytological diagnosis. 15 (9.6\%) were atypical, 7(4.5\%) were suspicious and in $72(46.2 \%)$ cases malignancy was diagnosed. In 3 $(1.9 \%)$ cases sample was unsatisfactory.

FNAC of the axillary lymph nodes was performed on 76 patients with palpable lymph nodes and histological correlation of axillary lymph node.

Table 2: FNAC and histology correlation of axillary lymph node

\begin{tabular}{|l|l|l|}
\hline & $\begin{array}{l}\text { Axillary lymph } \\
\text { node metastases } \\
\text { present }\end{array}$ & $\begin{array}{l}\text { Axillary lymph } \\
\text { node metastases } \\
\text { absent }\end{array}$ \\
\hline FNAC Positive & 59 & 0 \\
\hline $\begin{array}{l}\text { FNAC } \\
\text { Negative }\end{array}$ & 13 & 4 \\
\hline Statistic & Value & $95 \% \mathrm{Cl}$ \\
\hline Sensitivity & $81.94 \%$ & $71.11 \%$ to $90.02 \%$ \\
\hline Specificity & $100.00 \%$ & $39.76 \%$ to $100.00 \%$ \\
\hline $\begin{array}{l}\text { Positive } \\
\text { Likelihood } \\
\text { Ratio }\end{array}$ & & \\
\hline $\begin{array}{l}\text { Negative } \\
\text { Likelihood } \\
\text { Ratio }\end{array}$ & 0.18 & 0.11 to 0.30 \\
\hline $\begin{array}{l}\text { Disease } \\
\text { prevalence } \\
\text { (*) }\end{array}$ & & $87.07 \%$ to $98.55 \%$ \\
\hline $\begin{array}{l}\text { Positive } \\
\text { Predictive } \\
\text { Value (*) }\end{array}$ & $100.00 \%$ & $15.83 \%$ to $33.48 \%$ \\
\hline $\begin{array}{l}\text { Negative } \\
\text { Predictive } \\
\text { Value (*) }\end{array}$ & $23.53 \%$ & $72.53 \%$ to $90.57 \%$ \\
\hline Accuracy (*) & $82.89 \%$ & \\
\hline
\end{tabular}

\section{Discussion:}

FNAC is a simple rapid technique and can be performed as an outpatient procedure as compared to biopsy which has risk of bleeding and occasionally rare complications like pneumothorax. It is cost effective and does not require any anaesthesia or hospitalization. Experience and expertise in sampling and interpretation of specimen decide the effectiveness of FNAC. The limitation of FNAC is it cannot differentiate few lesions like fibroadenoma from phyllodes, phyllodes from metaplastic carcinoma breast, papilloma from papillary carcinoma, and atypical ductal hyperplasia from ductal carcinoma in situ. Though a triple assessment is advocated for all palpable breast lumps, it is not feasible in developing countries like India, where affordability and availability are an issue at all centers and clinical decision takes a major role. In a meta-analysis of FNAC of breast lesions showed a sensitivity and specificity of 0.920 (95\% $\mathrm{Cl}, 0.906$ to 0.933$)$ and $0.768(95 \% \mathrm{Cl}, 0.751$ to $0.784)$ respectively ${ }^{x i}$. False positives results can be reduced by considering for biopsy in patients fulfilling DeMay's criteria in cases with poor cellular aspirate, absent single intact cells, presence of bare bipolar nuclei, and absent/less amount of atypia ${ }^{x i i}$. FNAC in palpable lymph nodes were evaluated in a study which showed diagnostic accuracy for metastatic lymph nodes as $97.9 \%$, sensitivity of $97.9 \%$, and specificity of $100 \%{ }^{\text {xiii }}$. Our study showed sensitivity as $81.94 \%$ (95\% Cl $71.11 \%$ to $90.02 \%)$ and specificity as $100 \%$ (95\% Cl39.76\% to $100.00 \%$ ) with positive predictive value of $100 \%$.. FNAC is also cost effective and cost effectiveness of FNAC of breast was studied in a study by Silverman et al. They demonstrated less costs with FNAC of breast lesions $^{\text {xiv }}$. The most common reason for a false negative result may be the failure to localize the lesion exactly. Also, tumors with extensive fibrosis like scirrhous carcinoma can give a false negative result because of low cellularity which can be avoided by performing FNAC in the periphery of the tumor ${ }^{\mathrm{xv}}$.

\section{Conclusion}

To conclude FNAC is a rapid, cost effective and safe procedure for management of breast lumps. 


\section{References}

1. Siegel $R$, Naishadham D, Jemal A. Cancer statistics, 2012. CA Cancer J Clin. 2012 Jan-Feb; 62(1):10-29.

2. Giuliano $A E$, Connolly JL, Edge $S B$, Elizabeth $A$, Mittendorf, Rugo HS, et al. Breast cancer - Major changes in the American Joint Committee on Cancer eighth edition cancer staging manual. CA Cancer J Clin 2017;67:290-303.

3. Challa VR, Yale Guru BG, Rangappa P, Deshmane V, Gayathri DM. Cytological and Pathological Correlation of FNAC in Assessing Breast Lumps and Axillary Lymph Node Swellings in a Public Sector Hospital in India. Patholog Res Int. 2013;2013:695024. doi:10.1155/2013/695024

4. Saadatmand $S$, Bretveld R, Siesling S, TilanusLinthorst MM. Influence of tumour stage at breast cancer detection on survival in modern times: Population based study in 173797 patients. BMJ 2015;351:h4901.

5. Shek LM, Codolphin W. Model for breast cancer survival: Relative prognostic roles of axillary nodal status, TNM stage, estrogen receptor concentration and tumor necrosis. Cancer Res 1988;48:5565-9.

6. The uniform approach to breast fine-needle aspiration biopsy. NIH Consensus Development Conference. Am J Surg. 1997 Oct; 174(4):371-85.

7. Robles-Frias A, Campora RG, Martinez-Parra D, Robles-Frias M, Vazquez-Cerezuela T, Salaverri $\mathrm{CO}$, et al. Robinson cytologic grading of invasive ductal breast carcinoma. Correlation with histologic grading and regional lymph node metastasis. Acta Cytol 2005;49:149-53.

8. Moon HJ, Kim MJ, Kim EK, Park BW, Youk JH, Kwak JY, Sohn J, Kim SI. US surveillance of regional lymph node recurrence after breast cancer surgery. Radiology. 2009 Sep; 252(3):67381.

9. Khatcheressian JL, Hurley $P$, Bantug $E$, Esserman LJ, Grunfeld E, Halberg F, Hantel A, Henry NL, Muss HB, Smith TJ, Vogel VG, Wolff AC, Somerfield MR, Davidson NE, American Society of Clinical Oncology. Breast cancer follow-up and management after primary treatment: American Society of Clinical Oncology clinical practice guideline update. J Clin Oncol. 2013 Mar 1; 31(7):961-5.

10. Ahn HS, Kim SM, Jang M, La Yun B, Kim SW, Kang E, Park SY, Moon WK, Choi HY. Comparison of sonography with sonographically guided fineneedle aspiration biopsy and core-needle biopsy for initial axillary staging of breast cancer. J Ultrasound Med. 2013 Dec; 32(12):2177-84

11. Yu YH, Wei W, Liu JL. Diagnostic value of fineneedle aspiration biopsy for breast mass: a systematic review and meta-analysis. BMC Cancer. 2012 Jan 25; 12():41.

12. Demay RM. The Art and Science of Cytopathology: Aspiration Cytology. Vol. 2. Chicago, III, USA: USA ASCP press; 1996. Diseases and conditions of the breast; pp. 847-937.

13. Alam K, Maheshwari V, Haider N, Siddiqui FA, Jain $A$, Khan $A H$. Fine needle aspiration cytology (FNAC), a handy tool for metastatic lymphadenopathy. The Internet Journal of Pathology. 2010;10(2)

14. Silverman JF, Lannin DR, O'Brien K, Norris HT. The triage role of fine needle aspiration biopsy of palpable breast masses. Diagnostic accuracy and cost-effectiveness. Acta Cytol. 1987 NovDec; 31(6):731-6.

15. Vazquez MF. Needle biopsy diagnosis of breast cancer. In: Roses DF, editor. Breast Cancer. 2nd edition. chapter 17. 2008. pp. 271-289. 